\title{
Europeanization of Turkey and the Long Way to EU Membership
}

\section{Doina Gavrilov}

\author{
National School of Political and Administrative Studies, Bucharest, Romania \\ doina.gavrilov@yahoo.com
}

Keywords: Europeanisation, membership, European Integration

\begin{abstract}
For a few decades, Europe watches Turkey evolution in a matter of politics, policy, policies, human rights and so on. Everything begins in 1959 when Turkey applies to associate membership to the European Economic Community. But unfortunately for Turkey, the accession to the Community was not to accomplish. In time, the European Economic Community became the European Union. The organization pass through the enlargement process multiple times that today it is the Union of the 28 countries, but still without Turkey as a member. After all this time, a question is raised: what drags Turkey from achieving the membership status in all this time? In this paper, we try to answer the above question through the Europeanization spectrum.
\end{abstract}

\section{Introduction}

In the EU history, Turkey is the longest candidate country that still did not succeed to access to the EU membership. To answer why it is so hard for Turkey to accomplish this purpose authors have tried to answer from different points of view: "Turkey Muslim culture is a threat to the European identity" [31, p. 115], or that "Turkey represents a policy threat to the EU" [24, p. 486] and so on.

Giving the fact that the main requests of the EU are based on changes that Turkey should make to get closer to the EU market, policies, values and rules we decide to analyze Turkey problems to access to the EU membership through the Europeanization point of view.

Explaining Europeanization as a changing process which implies a change of the internal institutions, policies, politics, values, and rules of a country, and getting closer to the EU, including obtaining EU membership, will allow us to find the key factors that oppose to Turkey EU membership.

The research question is: Why Turkey is still not a member of the EU?

Starting with this, we note a few more questions that derive from the above question that we will answer along with our research: What is Europeanization? Is Turkey Europeanized enough to be an EU member? What is the hindrance to Turkey EU membership?

To understand why Turkey has problems in becoming an EU member we analyze the Europeanization concept, and we underline its importance in our research. After realizing the role of a Europeanised Turkey, we will focus to understand if Turkey is Europeanised or not. In both cases, if Turkey is Europeanised or not, we will focus on understanding why Turkey encounter difficulties in becoming an EU member.

We expect to see a meagre degree of Europeanization in Turkey looking at the internal events in the last years. In 2017 the referendum brings the proposition of a presidential system that threats the separation of powers in the state. The 2018 European Commission Report also underlines a severe problem with corruption, crime, human rights, the judicial system, migration and asylum policy, regional cooperation (where the EU asks Turkey to cooperate with Greece, Bulgaria, and Cyprus) [10].

Having a low degree of Europeanization will explain why Turkey is still not a member of the EU- because it did not change enough- but this finding will not help us understand why Turkey cannot get more Europeanised. To see what opposes to Turkey deepening of the Europeanization process we will focus on the main changes that should take place and the domains with which the change interact. This way, at the end of the paper we will find out how much Turkey is Europeanised and what is the hindrance to its Europeanization that stand against its EU membership. 


\section{What is Europeanization?}

Europeanization is a concept that appears in the research spectrum in the 1990s. At first, the authors have tried to define the new concept that was used differently by political representatives [32]. Despite all tries, in [5] Bulmer and Radaelli get to the conclusion that there is not a unique definition of Europeanization and that all the definitions the authors given are complementary and together build up a more or less complete image of the Europeanization process [5]. Some of these definitions describe the Europeanization as "a process of change" [6], or as a process that "describes a variety of phenomena and process of change" [33], "a domestic impact of the European Union" [19, p. 7]. After 2000, the definitions are more linked to the EU, as an example, Borzel and Risse define Europeanization as "a process of institution-building at the European level" [6, p. 3]. Ladrech sees it as "an incremental process reorienting the direction and shape of politics to the degree that EC political and economic dynamics become part of the organizational logic of national logic of national politics and policy-making" [20, p. 70].

Even all these definitions illustrated a part of the Europeanization process, in 2002, Radaelli brings a definition that is used by most authors later [26]. Radaelli describes Europeanization as "a process of construction, diffusion and institutionalization of formal and informal rules of procedures, political paradigms, styles and" ways of doing something "and the sharing of beliefs and norms that are first defined and consolidated in the development of EU policies and politics and then incorporated into the logic of domestic, identity, political and public policy discourse" [26, p. 108].

The definition he brings illustrates a top-down approach, which reflects the ideas of the neofunctionalist theory that the EU is the leading actor that triggers the change and formulates the models of change that the states should pursue.

We will use the neofunctionalist approach and Radaelli's definition to analyze Turkey Europeanization and how it fulfils the membership change requests.

Even Europeanization is defined as a more complex process, that includes not only a top-down perspective but also a bottom-up and inter-states perspective, being "a more than a two-way process" [14], we prefer to limit our research to this approach that is not so complex. The top-down perspective allows us to understand why Turkey is still not a member of the EU, what are the EU reasons to keep Turkey as a candidate country and also the reasons that Turkey refuses to pass through the complete process of change.

In 2012, Marciaq sustained the above idea. He underlines that for a better understanding of some details of the Europeanization is better to analyze an approach separately from the others that present the changing process as a complex one, difficult to study deeper [21].

Giving the fact that the Europeanization is generally understood as a process of change under the pressure of the EU, we will follow the main ideas of the neofunctionalist theory.

\section{Theoretical Approach}

We must underline the fact that the Europeanization definition reflects the neofunctionalist idea of EU being one of the central and influent actors in the international system. In the Europeanization research, the same idea is sustained not only by Radaelli but also by Featherstone, Borzel, Risse, etc.

Beside neo-functionalism, we have authors that pursue other research theories. T. Flockhart chose the historical and sociological theory. C. Radaelli in a few papers takes the constructivist approach. J. Olsen makes his research from the new institutionalist theory.

Some of these theories were criticized more than others, like constructivism. In 2015 I.G. Barbulescu underlined that many authors disregard constructivism as a theory [4]. The reason why it does not help us understand the Europeanization process is that it defines the European Integration as a process of change that equals to the Europeanization definition that is not necessarily the same.

One of the most explicit differentiation between the two notions was made in 2002 by Howell [16]. The author sees the European Integration as "the environment on which the Europeanization impacts or from which it emanates" and the Europeanization as the "interactive process, which involves bottom-up and top-down procedures or 'projection' and 'reception' “ [16, pp. 3-9]. 
Returning to the main ideas of the neofunctionalist theory, which is the most used theory in the research of both: Europeanization and European Integration, we decide to shape the main ideas of the theory, and finally to outline which ideas we will use the most to analyze the changing process in Turkey.

The neo-functionalist theory is based on three main ideas as follows:

1. "European integration once started triggers automatism, involving the integration of other domains;

2. non- state actors strongly influence decisions made by governments at the international level;

3. interest groups and political elites support integration into the European Union" [4, pp. 96]. The second is about the power of the non-state actors. Barbulescu underlines the importance that the EU has in the last years on its member states, candidate countries, and partners. He refers to change in a matter of products quality, of justice asked as a basic need to substantiate a collaboration, the Aquis to be fulfilled to be a member of the EU, and so on.

The first one, is about the spillover effect, referring to the changing process and the way the European ideas, laws, rules get to be incorporated in the national structures of a state without actually being planned or followed by the national state. This idea is linked to the third that sustains that in the national state are formed interest groups which support the change to happen. Also, it mentions the political elites that also sustain the change at the local level.

The research will be developed under the first idea. We will sustain that the change in Turkey happens because of the pressure the EU puts as a condition to become a member of the organization.

Next, we will focus on the changing process Turkey pursued in all these years.

\section{Turkey Fulfilling EU Requests}

We will start by sustaining that the EU asks Turkey to pass through the Europeanization process to accomplish the European level of development so it can accommodate to European competition, market, policies, justice, law and so on. This way the EU assures that the candidate country is stable in the main areas (politics, justice, economy and human rights) [25] and it can deal with the European rules, laws, and policies in the future as a member with complete rights in all the EU structures.

How did Turkey succeed to accomplish EU requests?

The EU attention is focused on Turkey from 1959 when Turkey has applied for membership at the Economic European Community. The following events after Turkey application enregister ups and downs. See Table 1.

Table 1. Evolution of Turkey -EU relation

\begin{tabular}{|c|c|}
\hline 13 December 1997 & Turkey is declared eligible for EU membership by the Luxembourg Council \\
\hline 11 December 1999 & Turkey becomes a candidate country \\
\hline 24 mars 2001 & The Council of the EU adopts Turkey Accession Partnership \\
\hline 19 May 2003 & Turkey Accession Partnership has been adopted after revision \\
\hline 16 December 2004 & $\begin{array}{l}\text { The European Council decided that Turkey accomplished the requested } \\
\text { change to open the negotiations for accession in } 2005\end{array}$ \\
\hline 3 October 2005 & The negotiations are formally opened \\
\hline 1 June 2006 & Turkey negotiated the chapter on science and research \\
\hline 11 December 2006 & $\begin{array}{l}\text { Because Turkey refused to apply the Additional Protocol to the Ankara } \\
\text { Agreement on Cyprus, the EU Council decided not to open five chapters of } \\
\text { negotiation. (The talks are put on hold for four years). }\end{array}$ \\
\hline 30 June 2010 & $\begin{array}{l}\text { The negotiations open on the food safety, veterinary and phytosanitary } \\
\text { policy. }\end{array}$ \\
\hline 05 November 2013 & $\begin{array}{l}\text { Turkey negotiates the regional policy and coordination of structural } \\
\text { instruments }\end{array}$ \\
\hline
\end{tabular}




\begin{tabular}{|l|l|}
\hline 16 December 2013 & $\begin{array}{l}\text { Turkey negotiates with the EU the visa liberalization for its citizens in the } \\
\text { EU }\end{array}$ \\
\hline 29 November 2015 & $\begin{array}{l}\text { Was held the first EU-Turkey Summit and activated the Joint EU-Turkey } \\
\text { Action Plan }\end{array}$ \\
\hline 14 December 2015 & Were opened the negotiations on the Economic and monetary policy \\
\hline 18 mars 2016 & EU-Turkey Statement \\
\hline 30 June 2016 & $\begin{array}{l}\text { Accession Conference on Turkey. Was opened the discussions on Financial } \\
\text { and budgetary provisions }\end{array}$ \\
\hline
\end{tabular}

Source: Author's Table after the European Commission, 2017

In 2016 Turkey begins its way of distancing from the EU. In the European Commission report from April 2018 we find that in the summer of 2016 Turkey is in a state of emergency because of the terrorist attacks. The EU finds the political area under threat because of the referendum on introducing the presidential system - a system that represents a danger for the separation of powers. The results of the referendum raised at the EU level questions on the impact of the referendum on the emergency state Turkey has had and also about the integrity of the election.

At the social level, the European Commission enregistered an increasing pressure expressed in a large number of arrests of activists and defenders of human rights. These facts have led to the limitation of the free space and aggravated the state of emergency.

From another point of view, the domains that were changing to allow Turkey the European Integration was not so evolved. Here the European Commission finds "the judicial system at an early stage of preparation" [10]. The human rights and freedom of speech are at the same stage as the judicial system. All of these brings to empowering of the corruption system and crime, which need to be diminished not encouraged. The state of emergency stops the changing process in all the domains.

Leaving aside these domains, in 2017 the EU opens the discussion on the Cyprus chapter, that has been postponed in 2006. In January 2017 in Geneva and July 2017 in Crans-Montana, the chapter was discussed and finally closed without an agreement. This aspect seems to be very important to the EU in a matter of peace.

The above aspect and the national state of emergency have pushed the EU to put the discussions with Turkey on hold until the basic chance is made. It means, even Turkey makes progress in applying the EU legislation at the formal level, practically when the freedom of speech and the human rights are under threat, the formal change does not constitute a strong point for the membership.

After we have seen that Turkey has had an increasing period of Europeanization and also a decreasing one starting with 2016, we will focus on finding why Turkey pass from a deepening Europeanization to a less Europeanized state where the fulfilled changes were modified against EU requirements.

\section{The Factors that Oppose Turkey Europeanization}

Factors that oppose to deepening the Europeanization process may be linked to the fears Turkey faces as much as its getting closer to the EU. Also, we can find factors that represent a boundary to Turkey membership by analyzing Turkey external policy orientations and national objectives.

One of the first national objectives of Turkey that comes with fear when it comes about Europeanization process is to preserve and keep untouched the national culture, values, rules, language, traditions and most important Turkey independence [28].

Another fear is that of being influenced by the European religions so that Muslim religion changes together with the traditions linked to it. It should also be mentioned that religion comes with traditions of doing politics and with some rules on human rights.

Therefore, if one of the above elements that constitute the basis of the Turkish national identity, the Europeanization process can change them all - what is not the purpose of Turkey collaboration with the EU. 
Giving the fact that the Europeanization process often comes with uncontrollable change, we find the fear of changing the basis of the nation - culture, and tradition.

In 2004, Giscard underlined that Turkey membership to the EU might signify the "triumph of the economics over culture." This statement meets another statement, that of John Casey from 2016, that says "Turkey is no longer a democratic, secular state, but more one of the Islam and Ottoman nostalgia" [7].

Even more, in 2002 Hasan Kosebalaban underlines that "despite 75 years of Westernization policies, the Turkish state ideology has not achieved a process of common identification with the West that would diminish its sensitivities to issues of national independence" [17]. This statement underlines that fact that Turkey formally was getting closer to the EU, but in the matter of Europeanization, the change was kept to the minimum. Why Turkey does this? Because the fear is based on the idea that "Turkish national sovereignty would be rendered meaningless by EU membership" [17].

The authors lead us to the idea that Turkey does not feel like a Western country, and does not follow the Western ideas, has lost the belief in EU intentions and does not identify itself as a European Country. These ideas are sustained even from 1997 by James Pettifer. In 2010 the same fact was observed by Alessandri, that raise the question "Does the West lose Turkey?" [1, p. 2].

In this context, we decided to focus on the other side of the Europeanization process, namely on how EU acts when it comes about Turkey.

\section{EU Attitude on Turkey}

Given the fact that the Europeanization process is a process of change sustained by the EU, the Organization should have an essential role in maintaining and/or deepening the change. Since the EU set the main directions of the Europeanization, we expect that the level of Europeanization in Turkey also depends on EU-Turkey relation.

In this part of the research, we will focus on observations that the authors have made until now on Turkey-EU relation.

First of all, let say that Turkey is not considered a compatible nation with the EU members. In 2004 Nergis Canefe and Mehmet Ugur sustains that "Turkey remains, for the moment, an outsider in the new European of nation-states" [29, p. 13]. The Christian Democratic Party also shares this idea in 1997, where it is sustained that "the European Union is a civilization project and within this civilization project Turkey has no place" [23].

In 2002 Hans-Ulrich Wehler underlines the same observation on Turkey's future within the EU, underlying that "technical, economically and institutionally oriented Europeanisation is not sufficient to transform into a European country, the precondition of genuine Europeanisation is a living democratic political culture, which does not exist in Turkey" [30, pp. 60-61].

The changing process in Turkey can be separated into two periods, where the direction the Europeanization process takes is different, and the deepness. According to Guney and Tekin, between 1999-2005, in Turkey, the change is characterized by democratic relations. After 2005, we assist at a period where the acquis communautaire is seen as a condition to maintain the relations with the EU and does not define anymore the democratic conditionality [12]. The second period goes until the Europeanization is barely noticed or not seen at all. In 2010, Gursoy said that "the Europeanization is not a noticed process in Turkey" [13].

Given the above observation, we decided to focus on EU attitude in relation with Turkey, to see if the Organization behavior is one of the reasons why after 2005 Turkey Europeanization is limited at a formal change.

In 2010 Katinka Barisch underlined that even the negotiation and the talks have started on 12 chapters, EU decided to close only one (science) and suspended eight because Turkey did not respect the Ankara protocol. The author observes that even in 2009 Turkey hardly succeeded to open two chapters [2].

We can say that the EU is too demanding in Turkey case. But at the same time we should not forget that Turkey still has issues at the political level, human rights, minority rights. Here we can add the problems in fulfilling EU requests about Association Agreement on the Cyprus relationship. 
The EU insists chiefly on the above areas as a fundamental condition of the membership. The European Commission from time to time elaborates reports on the evolution of the candidate countries in a matter of justice, security, policy, politics, policies, values, and norms. The European Commission published one of the latest reports on Turkey in 2016, where it underlines that the change in Turkey is not so profound and right. Looking at the internal state, the Commission outlines that the legislation in Turkey has been prepared and adopted without sufficient debate in the Parliament and consultation of the interested parties (European Commission, 2016).

So, looking at the EU - Turkey relation, many authors say that Turkey place is not in the European Union. Some authors question this assessment of Turkey Europeanization, its desire to become an EU member. One of the authors is Giannakopoulousm that in 2004 sustained that we can know for sure if Turkey can become a part of the European Integration process or not [15, p. 62].

Baycar is going further and says that Turkey represents more "a bridge between Orient and Occident" [3, p. 13]. The same idea is sustained in 2010 by Ingrid Kylstad. The author says that "the EU is a cultural union with a strong Christian heritage, and Turkey seems to be the eternal Other" [18].

Besides the fact that Turkey is reserved in the Europeanization process [27] it is also a state that does not accept the change so easy and profound as the member states of the EU did as candidate countries. One of the reasons is the religion. Baycar in 2013 says that "to the integration are going to oppose the Muslims" [3, p.18]. Another reason why Turkey oscillates, so much in the Europeanization process is the fear of losing the national identity [22].

Starting from the above statements, we can say that the EU has its guilt too by not giving enough attention to Turkey by sustaining the Europeanization process. In a way, its attention is focused on other problems like Brexit, Migrant crisis and Eastern security. But still, in all these years, it raises the question of "wishing to have Turkey in the EU". In 2011 Gokhan Saz wrote that "all these European countries have one thing in common: they have plenty of Turkish and Muslim immigrants and don't like the idea of Turkish membership. Therefore Religion is seen as a major stumbling block for Turkey on the quest for EU membership, since it is publically regarded as an Islamic country in Europe, despite its secular structure" [11, pp. 483-484]. In the same paper, the author underlines the negative perception of Turkey membership because of "high disapproval rates of Republic of Cyprus and Greece (because of Turkey relationship with these countries), Austria, France, and Germany (as countries with a higher number of Turkey immigrants" [11, p. 485].

After this, we tend to believe that the EU is responsible too for this long time in which Turkey did not achieve the member status.

\section{Conclusion}

Every time the European Union have had an enlargement process we expected to see Turkey closer to the membership. Against our expectations and the longest candidate story, Turkey did not succeed until now to get closer to the EU. Starting with the Europeanization idea, we analyzed the changing process in Turkey, the attention that the EU is according to this candidate country, the membership requests that Turkey fulfils or not.

First of all, we focused on the changing process, it identified in Turkey or not. After the European Commission report, we observe that the change is formal and questions the efficiency of these changes in the context of human right violations and other political changes that happen in Turkey in the last years. Beside this, we try to see Turkey's wish to change. What we observe is that there is a desire for keeping the political traditions, the fear of having the Turkish culture affected by the European rules, ideas and values. Also, we observe the desire to stay an independent state - the concern of being ruled by EU, constrained by the EU laws and so on.

And the last observation is about the attention the European Union gives to this candidate country, and the European citizens attitude on Turkish people. We see that comparing to other candidate countries; the EU does not manifest so much interest. The EU attitude describes a friendly relationship with Turkey. The EU actions in the last years suggest that the Organisation would like more to have Turkey as a partner than as a member because the fear of member accession is from both sides: Turkey and the EU. 
Finally, why Turkey is still not a member state of the EU?

After the research analysis, we get to the conclusion that three main problems restrict Turkey membership to the EU:

Turkey problems:

- Turkey refuses to fulfil EU requests in a matter of change at the national level.

- Turkey lack of trust in EU intentions.

EU problems:

- EU fear of not being able to manage Turkey membership.

- EU lack of implication in Turkey Europeanization process.

Citizens problems:

- The EU citizens fear of Turkey Islamic population.

- Turkey citizens fear of being treated as strangers in the EU.

These problems can be seen as key factors that influence Turkey chance to be an EU member. Still, starting from the above issues, in the next few years, we do not expect to see Turkey as an EU member. Both, the EU and Turkey are afraid of such a significant change. This has been the main reason why for so many years Turkey accession to EU membership has been postponed and rediscussed at both levels: EU and Turkey.

In the near future, we expect to see Turkey as a strong partner of the EU, and also as an influential actor in the Middle East. From the other side, we expect to see the EU supporting Turkey to embrace the European laws, ideas, values, rules and 'way of doing things'.

\section{Conflict of Interest}

The author declares that there is no conflict of interest.

\section{References}

[1] E. Alessandri, The new Turkish Foreign Policy and the Future of Turkey-EU relations, Instituto Affari Internazionali. (2010) 1-19. Available: https://www.files.ethz.ch/isn/124971/iai100 3.pdf.

[2] K. Barisch, Can Turkey combine EU accession and Regional Leadership? Centre for European Reform. Policy Brief. (2010) 1-11.

[3] N. Baycar, Turkish Cultural Identity: A European identity, Turkish Journal of Politics. 4(2) (2013) 5-21.

[4] I.-G. Bărbulescu, Noua Europă. Identitate și model european, Iași: Polirom, 2015.

[5] S. Bulmer, C.M. Radaelli, The Europeanization of Member State Policy, in: S. Bulmer, C. Lequesne, The Member State of The European Union, Oxford: Oxford University Press, 2013, pp. 357-383.

[6] T. Borzel, T. Risse, When Europe Hits Home: Europeanization and Domestic Change, European Integration Online Papers (EIoP). 4(15) (2000) 1-20.

[7] J. Casey, Turkey is not a part of Europe-as the history of our continent shows, Independent, 2016. Available: https://www.independent.co.uk/voices/turkey-is-not-part-of-europe-as-thehistory-of-our-continent-shows-a6923486.html.

[8] European Commission, Commission Staff Working Document. Turkey 2016 Report, 2016, 11 09. Retrieved: 01.25.2017. Available: https://ec.europa.eu/neighbourhoodenlargement/sites/near/files/pdf/key_documents/201. 
[9] European Commission. (2017, 11 22). European Neighborhood Policy and Enlargement Negotiations. Retrieved: 01 02, 2019. From European Commission: https://ec.europa.eu/ neighbourhood-enlargement/countries/detailed-country-information/turkey_en

[10] European Commission. (2018, 04 17). Key findings of the 2018 Report on Turkey. Retrieved: 12 28, 2018. From European Commission Press Release Database: http://europa.eu/rapid /press-release_MEMO-18-3407_en.htm

[11] S. Gokhan, Turkophobia and rising Islamophobia in Europe: a quantification for the negative spillovers on the EU membership quest of Turkey, European Journal of Social Sciences. 19(4) (2011) 279-491.

[12] A. Guney, A. Tekin, The Europeanization of Turkish Public Policies. A scorecard, New York: Routledge, 2016.

[13] Y. Gursoy, Democratization and Foreign Policy Reforms in Turkey: Europeanization of Turkish Politics?, International Journal of Legal Information the Official Journal of the International Association of Law Libraries. 38(2) (2010) 227-234.

[14] P. Graziano, M. Vink, Europeanization: concept, theory, and methods, in: S. Bulmer, C. Lequesne, The Member States of the European Union, Second Edition, Chapter 2, Oxford: Oxford University Press, 2013, pp. 31-54.

[15] A. Giannakopoulos, What is to become of Turkey in Europe? European Identity and Turkey's EU Accession, Perceptions: Journal of International Affairs. (2004) 59-72.

[16] K. Howell, Developing Conceptualizations of Europeanization and European Integration and European Integration: Mixing Methodologies, ESRC Seminar Series/UACES Study Group on the Europeanization of British Politics. (2002) 1-27.

[17] H. Kosebalaban, Turkey's EU Membership: A clash of security cultures, Middle East Policy Council. 9(2) (2002).

[18] I. Kylstad, Turkey and the EU: a new European identity in the making? LEQS. 27 (2010) 1-24.

[19] R. Ladrech, Europeanization and political parties, Living Reviews in European Governance. 4(1) (2009) 1-17.

[20] R. Ladrech, Europeanization of Domestic Politics and Institutions: The case of France, Europeanization of Domestic PolitJournal of Common Market Studies. 32(1) (1994) 69-87.

[21] F. Marciaq, The Political Geographies of Europeanisation: Mapping the Contested Conceptions of Europeanisation, Journal of Contemporary European Research. 8(1) (2012) 57-74.

[22] L.M. McLauren, Opposition to the European integration and fear of loss of international identity: debunking a basic assumption regarding hostility to the integration project, European Journal of Contemporary European Research. 43 (2004) 895-912.

[23] M. Muftuler-Bac, The never-ending story: Turkey and the European Union, Middle Eastern Studies. 34(4) (2006) 240-258.

[24] N. Nugent, The EU's response to Turkey's membership application: not a weighing of costs and benefits, Journal of European Integration. 29(4) (2007) 481-502.

[25] K. Piri, Turkey: changing the constitution could end up in freezing EU accession talks, European Parliament, 2017. Available: http://www.europarl.europa.eu/news/en/pressroom/20170619IPR777 14/turkey-changing-the-constitution-could-end-up-in-freezing-euaccession-talks.

[26] C. Radaelli, The domestic impact of European Union Public Policy: notes on concepts, methods, and the challenge of empirical research, Politique Europeenne. 5 (2002) 105-136. 
[27] N. Tocci, Turkey and the European Union. A journey in the unknown, Brookings: Center of the United States and Europe, 2014.

[28] Turkish Cultural Foundation. (2016, 11 09). Turkish Culture. Retrieved 01.13.2017. From Turkish Cultural Foundation: http://www.turkishculture.org/ general-1067.htm

[29] M. Ugur, N. Canefe, Turkey and the European Integration. Accession prospects and issues, London, New York: Routledge, 2004.

[30] H.U. Wehler, Das Turkenproblem, in: A. Giannakopoulos, What is to become of Turkey in Europe? European Identity and Turkey's EU Accession, 2004, pp. 59-72. Available: http://www.sam.gov.tr/wp-content/uploads/2012/01/Angelos-Giannakopoulos.pdf.

[31] A. Yukleyen, Compatibility of Islam and Europe: Turkey's EU Accession, Insight Turkey. 11(1) (2009) 115-131.

[32] K. Featherstone, Introduction. In the Name of "Europe", in: K. Featherstone, C. Radaelli, The Politics of Europeanization, Oxford: Oxford University Press, 2003.

[33] J.P. Olsen, The many faces of Europeanization, Journal of Common Market Studies. 40(5) (2002) 921-952. 